ISSN1027-5495. Functional Materials, 25, No.2 (2018), p. 342-347

doi:https://doi.org/10.15407/fm25.02.342

(C) 2018 - STC “Institute for Single Crystals"

\title{
The modeling of the composition and properties of functional materials based on polytetrafluoroethylene
}

\author{
K.V.Berladir, T.P.Hovorun, O.A.Bilous, S.V.Baranova \\ Sumy State University, Str. Rimsky-Korsakov, 2, 40007 Sumy, Ukraine
}

Received January 15, 2018

\begin{abstract}
Design and creation of new structures of three-component antifriction composite materials are based on the researches modeling their behavior in the conditions of tension. In the presented models the uniform approach based on the variation principles of mechanics of a solid body and allowing formulating boundary value problems in the form of a condition of minimality of functionality is used. The multifactoriality of the dependence of wear of a composite on its elasticity, viscoplasticity and durability is considered. Macroscopic characteristics of composite material are directly connected with its structure which is characterized by spatial distribution of components and their properties.

Keywords: polytetrafluoroethylene, three-component composite material, structure, elasticity, plasticity, strength.

Проектирование и создание новых структур трехкомпонентных антифрикционных композитных материаловоснованынаисследованиях, моделирующихихповедениев условиях напряжения. В представленных моделях использован единый подход, основанный на вариационных принципах механики твердого тела и позволяющий сформулировать краевые задачи в виде условия минимальности функционала. Учитывается многофакторность зависимости изнашивания композита от его упругости, вязкопластичности и прочности. Макроскопические характеристики композитного материала непосредственно связаны с его структурой, которая характеризуется пространственным распределением компонентов и их свойствами.
\end{abstract}

Моделювання складу та властивостей функціональних матеріалів на основі політетрафторетилену. Х.В.Берладір, Т.П.Говорун, О.А.Білоус, С.В.Баранова

Проектування та створення нових структур трикомпонентних антифрикційних композитних матеріалів засновані на дослідженнях, що моделюють їх поведінку в умовах напруги. У представлених моделях використаний единий підхід, який заснований на варіаційних принципах механіки твердого тіла та дозволяе сформулювати крайові задачі у вигляді умови мінімальності функціоналу. Враховуеться багатофакторність залежності зношування композиту від його пружності, в'язкопластичності та міцності. Макроскопічні характеристики композитного матеріалу безпосередньо пов'язані з його структурою, яка характеризується просторовим розподілом компонентів і їх властивостями.

\section{Introduction}

Polymer composite materials (PCM) and coatings on their basis have recently found their effective application:

- in friction junctions due to good tribotechnical characteristics [1-3];

- in protection of the surface layers of hydroforming alloys from oxidation [4];
- as thermoresistant protective coatings that are able to prevent from oxidizing the active surface of metals and to endure temperatures necessary to activate intermetal compounds [4];

- as composite coatings to increase durability and corrosion resistance of magnesium, titanium, aluminum alloys that are widely used in aviation, automobile and electronic industries $[5,6]$; 
- to extend the exploitation period of metallic surfaces, to improve their corrosion resistance and to protect the metal from the negative environment influence [7, 8].

The intensity of wear of PCM depends greatly on mechanical properties, nature, structure and sizes of particles of matrix and fillers, composite material structure, its hardness, toughness, elasticity, level of the external force effect on the contact "composite - counterbody".

The composite wear depends on the fact how effectively the composite material microstructure can resist different processes of the material separation during the deformation. The main contribution into the amount of wear is made by the chain of plastic deformations and break in the thin surface layer. The distribution of the energy absorbed by the active layer determines the kinetics of accumulating damages and breaks and change of friction processes.

A polymer material should have high resistance to viscoplasticity and plastic deformations, hardness and fluidity limit and at the same time it should be plastically deformable. Thus, there appears a task to calculate mechanical characteristics of three-component polymer composites with a binary filler according to the properties of the initial ingredients.

The authors of the article [9] suggest that the characteristics describing the ability of the material to be worn during friction should be the correlation of its hardness $\mathrm{H}$ to the elasticity modulus of $\mathrm{E}$, in the paper [10] the hardness is substituted with the viscosity.

One of the ways to solve the given task is to establish functional dependence of composite material physico-mechanical properties on spatial distribution, arrangement scheme, geometrical forms and physico-mechanical characteristics of components of which it consists. Such investigations require solving some boundary value problems of composite material mechanics that describe these or those deformation processes. Another approach that is applied in this paper allows to employ variation principles of mechanics of a solid body and formulate boundary value problems as the condition of minimality of functionality $\Phi(v)$ on the set of possible shifts $v$ or their velocities [11, 12]. Such an approach is the reflection of the fundamental energetic principle which states that some functionality of an energetic type takes the minimal value only on the values of variables that are solutions of a boundary value problem.

The basic structures for investigation are three-component composite materials whose structure is constituted by the matrix (PTFE) that is statistically homogeneously reinforced with the inclusions of different geometrical forms (Fig. 1).

The paper studies the possibilities to create three-component tribotechnical materials on the basis of PTFE whose fillers can be carbonic and basalt fibers as well as dispersed particles - kaolin or coke. The starting data were physico-mechanical and geometrical characteristics of the material components.

The task consists in designing composite materials of different structure that combine necessary properties of elasticity, viscosity, plasticity with high wear resistance that enables the application of these materials for the products of tribotechnical purpose.

The relations of coherence of elastic and plastic properties are taken as the criteria that describe the ability of the composite material to abrasive wear resistance:

$$
T=k^{*} / E^{*},
$$

where $k^{*}$ - the limit of the composite material plasticity, $E^{*}$ - the modulus of elasticity.

Then the task to design wear-resistant materials will consist in determining such structures of composites under which this criterion takes the maximal value. The basic variable parameters are spatial concentrations of fillers.

\section{Choice of a model and methods of investigation}

Let us deal with the two-phase composite material of an occasional structure that consists of the continuous polymer matrix reinforced with the random distribution of discrete inclusions in it (Fig. 2).

The choice of a two-phase material as an object of investigation somehow simplifies (in comparison with a three-component composite) mathematical presentations and at the same time contains all the hypotheses and starting assumptions of further investigations.

In such a formulation a three-component composite can be presented as a hierarchical structure $[10,11]$ :

- the first level - matrix conglomerate - the matrix with the inclusions of the first type;

- the second level - the structure of a composite - the matrix conglomerate with the inclusions of the second type.

We design inclusions with the ellipsoid of revolution with the half-axes $a$ and $b$ that allows us to show different geometrical forms - both the inclusions in the form of dispersed spherical particles $(a=b)$ and the matrix reinforced with short fibers (the correlation of halfaxes $a / b$ of the ellipsoid determines the ratio of the fiber length to the diameter $-a / b \approx l / d$, 

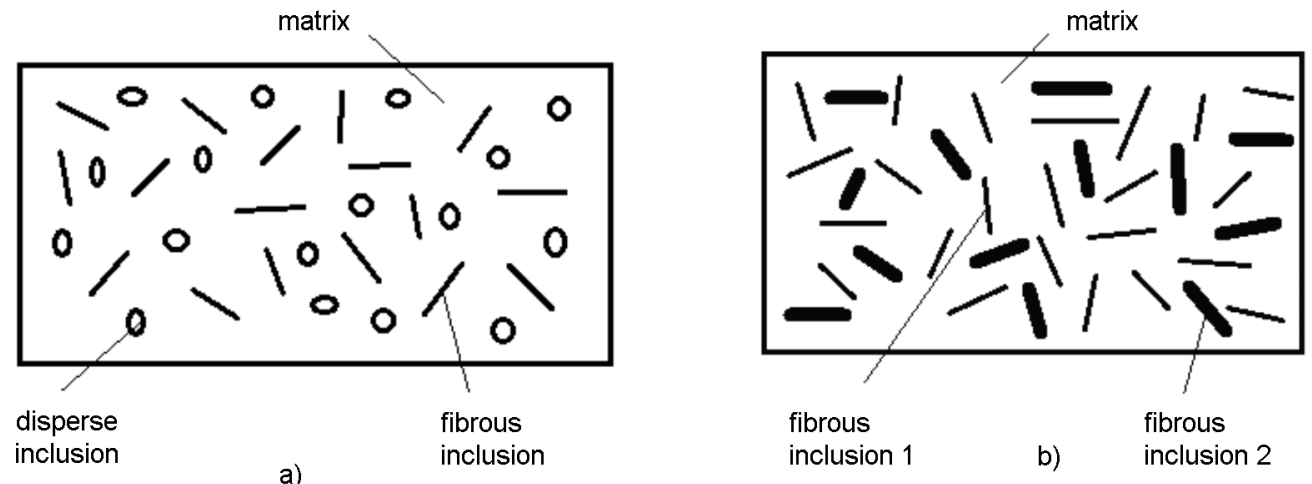

Fig. 1. Structure of three-component material based on PTFE filled: a) disperse and fibrous inclusions; b)fibrous inclusions of two types

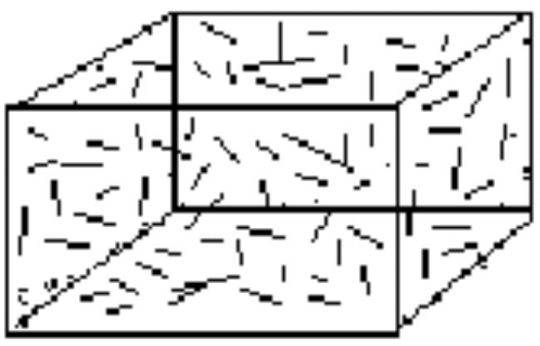

a)

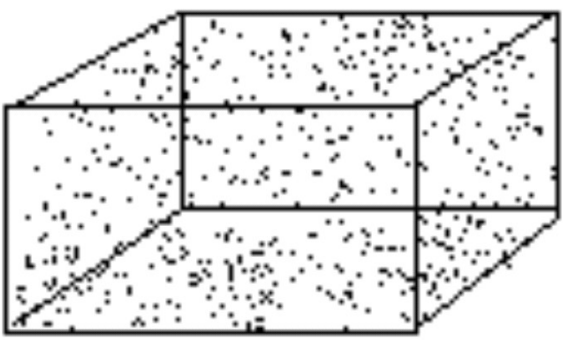

b)

Fig. 2. Structure of two-component material based on PTFE filled: a) fibers; b) disperse filler

where $l$ is the average length of the fibers, $d$ is their diameter).

Let us apply the hypothesis of ergodicity according to which averaging the random variables as to the material volume $V$ coincides with the statistical averaging (as to the ensemble of realizations) and average values as to the volume will be marked $V$

$$
(\langle\bullet\rangle)=\frac{1}{V} \int(\bullet) d V \text {. }
$$

The geometrical structure of the material is described with indicator random functions of the coordinates that take the value of one around the inclusions of the $n$-direction and a zero - otherwise. In this case

$$
\left\langle\chi_{n}\right\rangle=\frac{1}{V} \int_{V} \chi_{n} d V=\frac{1}{V} \int_{V_{n}} d V=\frac{V_{n}}{V}=c_{n},
$$

where $c_{n}$ - concentration of the inclusions oriented in the $n$-direction.

Random fields of tensions, deformations, shifts and indicator functions will be presented as a sum of mathematical expectations and fluctuations:

$$
\begin{gathered}
\sigma_{i j}=\left\langle\sigma_{i j}\right\rangle+\sigma_{i j}^{\prime}, \quad e_{i j}=\left\langle e_{i j}\right\rangle+e_{i j}^{\prime}, \\
u_{i}=\left\langle u_{i}\right\rangle+u_{i}^{\prime}, \quad \chi_{n}=\left\langle\chi_{n}\right\rangle+\chi^{\prime} .
\end{gathered}
$$

In accordance with the consistent variation approach we investigate the deformation of a composite material within elasticity and viscoplasticity, determine macroscopic properties and determine the material structure based on the assumed criterion of wear-resistance.

\subsection{Calculation of elasticity properties}

Let us consider both phases (matrix and inclusions) in the composite material isotropic, tightly connected along the interface (continuous shifts during transition across the interface) and we will indicate the elastic deformation energy correlated with the volume $V$ as

$$
\langle W\rangle=\frac{1}{V}\left(\int_{V-V_{1}} W_{1} d V+\sum_{n} \int_{V_{n}} W_{2} d V\right),
$$

where $\quad W_{1}=\mu e_{i j} e_{i j}+\frac{1}{2} \lambda e_{l l}^{2}$,

$$
W_{2}=\mu_{1} e_{i j} e_{i j}+\frac{1}{2} \lambda_{1} e_{l l}^{2} \text {. }
$$

Let us go over to the markers of the average values accepted above and introduce some limitation to the field of possible kinematic deformations making the following assumption in the functionality $\left\langle e_{i j} e_{i j}\right\rangle_{n} \approx\left\langle e_{i j}\right\rangle_{n}\left\langle e_{i j}\right\rangle_{n}$, and we will get 


$$
\begin{aligned}
& \langle W\rangle=\mu\left\langle e_{i j} e_{i j}\right\rangle+\frac{1}{2} \lambda\left\langle e_{l l}^{2}\right\rangle+ \\
& +\sum_{n}\left(\bar{\mu}_{1} c_{n}\left\langle e_{i j}\right\rangle_{n}\left\langle e_{i j}\right\rangle_{n}+\frac{1}{2} \bar{\lambda}_{1}\left\langle e_{l l}^{2}\right\rangle_{n}\right)
\end{aligned}
$$

The variation of the functionality on the independent fluctuations of the shifts $\delta u_{i}^{\prime}$ contributes to the minimality of functionality condition

$2 \mu e_{i j, j}^{\prime}+\lambda e_{l l, i}^{\prime}+\sum_{n}\left(2 \bar{\mu}_{1} \chi_{n, j}^{\prime}\left\langle e_{i j}\right\rangle_{n}+\bar{\lambda}_{1} \chi_{n, i}^{\prime}\left\langle e_{l l}\right\rangle_{n}\right) \underset{(2.6)}{=}=0$.

The acquired system of differential equations determines fluctuations of the field of composite deformations. After multiplying by $\chi_{m}^{\prime}$ and averaging of the acquired value according to the volume $V$ its answer determines the necessary functional connection.

When there is some spatial statistically homogeneous reinforcement one can apply the procedure of the transition to isotropic properties, then the obtained formulae of module of elasticity are given below.

The modulus of elasticity of the composite $E^{*}$ for the structure of a composite material with short fiber inclusions is defined by the formula

$E^{*}=E /\left[1+\left(1-c_{f}\right) /\left(Q c_{f}\right)+E /\left(E_{f}-E\right)\right]$,

where $E, E_{f}$ - modulus of elasticity of the matrix and fiber inclusions, $c_{f}-$ volume content of fibers in the composite material, $Q$-function of geometrical parameters of fibers that is defined through the parameter $\alpha=\sqrt{1-z^{2}}, \quad z=\frac{d}{l}$ where $d$ - the fiber diameter, $l$-its length.

$$
\begin{gathered}
Q=2\left\{1+0,1 /\left[6 R_{2}+E /\left(E_{f}-E\right)\right]\right\}, \\
R_{1}=\frac{1-\alpha^{2}}{4 \alpha^{5}}\left[\left(3-\alpha^{2}\right) \frac{1}{2} \ln \frac{1+\alpha}{1-\alpha}-3 \alpha\right], \\
R_{2}=\frac{3}{8}\left[1-4 R_{1}-R_{3}\right], \\
R_{3}=\frac{1-\alpha^{2}}{\alpha^{5}}\left[\left(1-\alpha^{2}\right) \alpha+\frac{1}{2}\left(1-\alpha^{2}\right) \ln \frac{1+\alpha}{1-\alpha}\right] .
\end{gathered}
$$

For the structure of the composite material whose matrix is reinforced with inclusions of the spherical form the modulus of elasticity of the composite $E^{*}$ is defined by the formula

$$
\begin{gathered}
E^{*}=E\left\{1+Q_{1} c_{s} /\left(1-c_{s}\right)\right\}, \\
Q_{1}=1 /\left[E /\left(E_{s}-E\right)+0,4\right],
\end{gathered}
$$

where $E, E_{s}$ - modulus of elasticity of the matrix and dispersed inclusions, $c_{s}$-volume content of dispersed inclusions, $Q_{1}-$ the function of elastic properties.

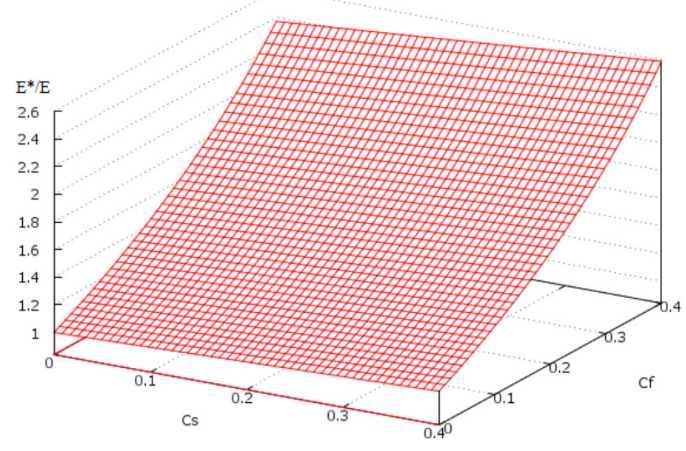

a)

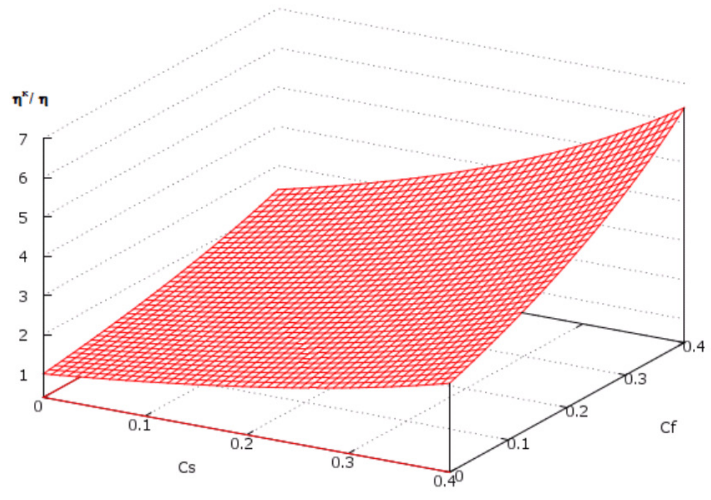

b)

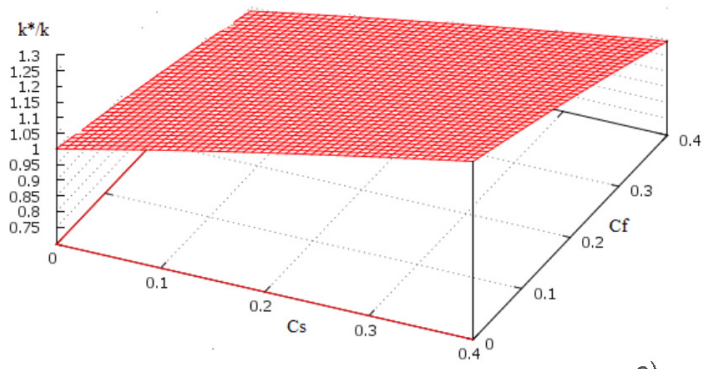

c)

Fig. 3. Dependences of elasticity (a), viscosity (b) and plasticity (c) of a three-component PTFEcomposite

\subsection{Calculation of viscoplasticity prop- erties}

Let us formulate the variation task of defining viscoplasticity properties of a two-component composite material as the condition of the extremity of the functionality $W^{*}$ that represents the dissipative function [12-14]

$$
\begin{aligned}
W * & =\frac{1}{V} \int_{V-V_{1}}\left(k \sqrt{\varepsilon_{i j} \varepsilon_{i j}}+\frac{1}{2} \eta \varepsilon_{i j} \varepsilon_{i j}\right) d V+ \\
+ & \frac{1}{V} \int_{V_{1}}\left(k_{1} \sqrt{\varepsilon_{i j} \varepsilon_{i j}}+\frac{1}{2} \eta_{1} \varepsilon_{i j} \varepsilon_{i j}\right) d V
\end{aligned}
$$

where the index 1 marks values that belong to inclusions, $k$ - the limit of material plastic- 


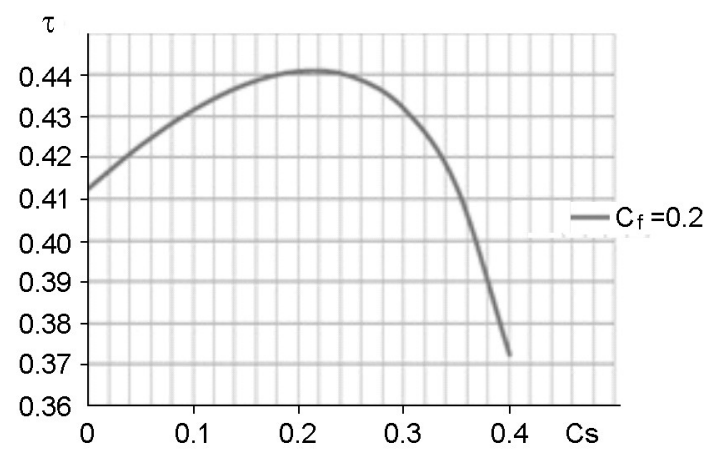

Fig. 4. Criterion of coherence of properties

ity, $\eta$ - the material viscosity, $\varepsilon_{i j}$ - deformation rate.

The functionality minimization according to (2.11) along fluctuations $\varepsilon_{i j}^{\prime}$ under the fixed values $\left\langle\varepsilon_{i j}\right\rangle$ lead to the parameter $\mathrm{W}^{*}\left(\left\langle\varepsilon_{i j}\right\rangle\right)$ calculation that will finally determine the value of tensions $\left\langle\sigma_{i j}\right\rangle=\partial \mathrm{W}^{*} / \partial\left\langle\varepsilon_{i j}\right\rangle$.

Depending on the tensions $\left\langle\sigma_{i i}\right\rangle$ the deformation process is possible when the inclusions behave as stiff particles. For such a state of deformation $\left(I_{1}=0\right)$ we have

$$
\begin{gathered}
W^{*}=k \sqrt{1-c_{1}} I+\frac{1}{2} \eta I^{2}, \\
I_{0}=\frac{2}{5}\left(1-c_{1}\right) \frac{k_{1}}{\eta+k \sqrt{1-c_{1}} / I}, \\
I^{2}=I_{0}^{2}+\frac{2}{5} c_{1}\left(1-c_{1}\right) k_{1}^{2} /\left(\eta+k \sqrt{1-c_{1}} / I\right)^{2} .
\end{gathered}
$$

Let us assume for the purpose of simplifying that the inclusions (both fibers and dispersed particles) are absolutely solid in comparison with the matrix (PTFE). Then the functional dependency of the plasticity limit of the composite with the dispersed particles will acquire such a type

$$
k^{*}=k \sqrt{1+1,5 \mathrm{c}_{\mathrm{S}}},
$$

and in the case of short fiber inclusions

$$
\begin{gathered}
k^{*}=k \sqrt{1+\left(Q_{2}-1\right) \mathrm{c}_{\mathrm{f}}}, \\
Q_{2}=\frac{1-\frac{2\left(1-8 R_{1}-7 R_{2}\right)}{5\left(1-4 R_{1}-5 R_{2}\right)}+\frac{2\left(R_{1}-R_{2}\right)}{15 R_{2}}}{2\left(2 R_{1}+R_{2}\right)} .
\end{gathered}
$$

The method of viscoplasticity analogy by Walter allows obtaining the correlation that defines the viscosity of a composite material. In view of the condition of absolute stiffness of inclusions in comparison with the matrix we obtain for the composite material of the first level (the matrix reinforced dispersedly with inclusions of the spherical form):

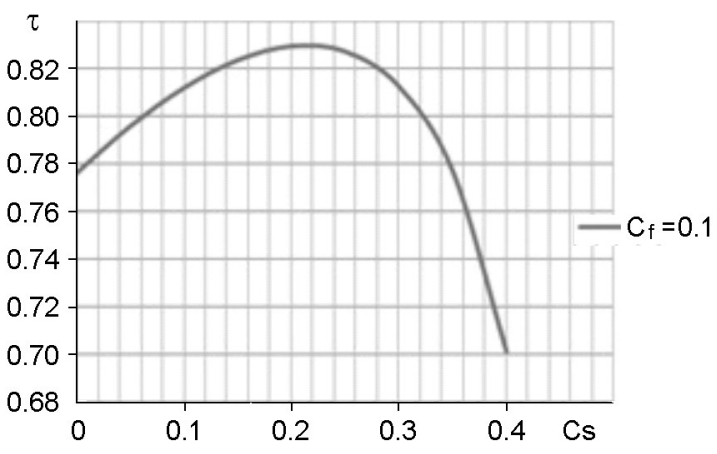

$$
\begin{aligned}
\eta^{*} & =\eta\left(1+2,5 c_{s} /\left(1-c_{s}\right)\right), \\
\eta^{k} & =\eta *\left(1+Q c_{f} /\left(1-c_{f}\right)\right),
\end{aligned}
$$

where $\eta$ - the matrix viscosity, $c_{\mathrm{s}}$ - volume content of the dispersed particles, $c_{f}$ - volume content of the fiber filler, $Q$ is defined through the correlation (2.7).

\subsection{The criterion of abrasive resistance}

Regarding the complexity of the polyfactorial process of wear that is influenced by material elasticity, viscosity and plasticity properties we suggest the following algorithm to analyze the structures of composite materials that ensure high antifriction properties:

- study possible achievements of the necessary physico-mechanical parameters by the composite material by means of correlations (2.7), (2.9), (2.13), (2.14), (2.15) that makes them reliable in the usage;

- introduce the criterion of the composite material coherence in the form of the relation of the material plasticity to its elasticity $T=k^{*} / E^{*}$ or in the dimensionless form

$$
\tau=T / T_{0}=\left(k^{*} E\right) /\left(k E^{*}\right) ;
$$

- find volume contents of inclusions that ensure the optimal criterion values (2.16). We assume that the obtained structure of the composite material is optimal and it ensures the high wear-resistance.

\section{Results and discussion}

The three-component composite structure is investigated. Its constituents are PTFE-matrix that has the modulus of tension $E_{m}=410 \mathrm{MPa}$; carbon fibers with the ratio $d / l=0,085$ and the modulus of tension $E_{f}=35 \mathrm{GPa}$; dispersed particles of coke with the diameter (10-50) $\mu \mathrm{m}$ and the modulus of tension $E_{\mathrm{s}}=500 \mathrm{MPa}$.

Fig. 3 shows the calculations of tension and viscoplasticity of the three-component structure under investigation. 
The calculation choice of structure components that ensures high wear-resistance according to the criterion of coherence of properties is shown on Figure 4. In this research fiber composite content is fixed (the values are given in the legend on the charts), depending on the content of dispersed particles (coke) the maximum of the criterion of coherence of properties is searched.

The data analysis (Fig. 4) has shown that while designing the three-phase structure of a composite material on the basis of PTFE reinforced with the volume content of carbonic fibers in quantity $c_{f}=0,2(20 \mathrm{wt} . \%)$ або $c_{f}=0,1$ (10 wt. \%), another component (dispersed coke particles) should be taken in quantity $c_{s}=0,2$ as to the volume content (20 wt. \%) that will ensure the maximum of wear-resistance according to the accepted criterion.

The methodology was approbated on the calculations of the real three-component materials of the tribotechnical purpose that are used in friction junctions.

\section{Conclusions}

The model and algorithm to search structures of three-component composite materials with the polymer matrix based on PTFE are suggested that ensure high wear-resistance indicators according to the criterion of coherence of plasticity and elasticity properties. The basis of the calculation of properties is the consistent variation approach. It is calculated that in the process when a three-phase structure of the material based on PTFE reinforced with the volume content of CF $(10-20)$ wt. \% is designed, another component (dispersed coke particles) should be taken in quantity $(20-22)$ wt. \% that will ensure the wear-resistance maximum in accordance with the accepted criterion.

\section{References}

1. A.A.Berlyn, Polymernye kompozytsyonnye materyaly: struktura, svoystva, tekhnolohyya, Professiya, Saint Petersburg (2011) [in Russian].

2. K.V.Berladir, T.P. Hovorun, V.A. Sviderskiy, P.V. Rudenko, M.V. Vyshehorodtseva, J. NanoElectron. Phys., 8(1), 01033-1 (2016).

3. A.Asadi, M.Miller, R.J. Moon, K.Kalaitzidou, Express Polym. Lett., 10, 587 (2016).
4. M.Yu.Zadorozhnyy, L.K.Olyfyrov, O.V. Bermesheva, V.Yu.Zadorozhnyy, Sovremennye Problemy Nauki i Obrazovania, 6, 83 (2012) [in Russian].

5. M.Yu.Zadorozhnyy, S.N.Klyamkin, D.V.Strugova, L.K.Olifirov, G.S.Milovzorov, S.D.Kaloshkin, V.Yu. Zadorozhnyy, Int. J. Energy Res., 40, 273 (2016).

6. S.V.Hnedenkov, S.L.Synebryukhov, D.V.Mashtalyar, Y.M. Ymshynetskyy, K.V.Nadaraya, D.P.Kyryukhyn, V.M.Buznyk, Novosty Materialoved. Nauka i Tekhnyka, 2, 32 (2015)

7. S.V.Hnedenkov, S.L.Synebryukhov, D.V.Mashtalyar, V.M.Buznyk, A.M.Emel'yanenko, L.B.Boynovych, Fizikokhimiya Poverkhnosti $i$ Zashchita Materyalov, 47(1), 86 (2011).

8. V.S.Rudnev, A.A.Vaganov-Vil'kins, T.P.Yarovaya, A.D.Pavlov, Surf. Coat. Techn., 307, 1249 (2016).

9. S.A.Fyrstov, V.F.Horban', E.P.Pechkovskyy, Materyaly XLVI Mezhd. Konf. «Aktual'nye problemy prochnosty», Vytebsk (2007).

10. H.O.Sirenko, L.V.Bazyuk, A.F.Budnyk, S.P.Shapovalov, Fiz. Khim. Tverd. Tila, 12, 727 (2011) .

11. V.V.Dudukalenko, Vestnyk CHHPU ym. Y.YA. Yakovleva. Seriya: Mekhan. Predel'nogo Sostoyaniya, 2(10), 25 (2011).

12. V.Y.Kolesnykov, V.V.Bardushkyn, A.V.Lapytskyy, A.P.Sychev, V.B.Yakovlev, Vest. Yuzhn. Nauch.Tsentra RAN, 6(1), 5 (2010).

13. V.L.Berdichevsky, Variational Principles of Continuum Mechanics. Interaction of Mechanics and Mathematics. I. Fundamentals, Springer (2009).

14. K.V.Berladir, O.A.Budnyk, K.O.Dyadyura, V.A.Sviderskyy, P.V.Rudenko, S.P.Shapovalov, V.B.Yuskayev, Naukovi Osnovy Rozrobky Polimernykh Kompozytsiynykh Materialiv Trybotekhnichnoho Pryznachennya na Osnovi Politetraftoretylenu, Sumy State University, Sumy (2017) [in Ukraine]. 